\title{
Breast Cancer pN1c TNM Finding v7
}

National Cancer Institute

\section{Source}

National Cancer Institute. Breast Cancer pN1C TNM Finding v7. NCI Thesaurus. Code C88355.

Breast cancer with metastases in 1 to 3 axillary lymph nodes and in internal mammary lymph nodes with micrometastases or macrometastases detected by sentinel lymph node biopsy but not clinically detected. "Not clinically detected" is defined by imaging studies (excluding lymphoscintigraphy) or by clinical examination. (from AJCC 7th Ed.) 